exhibited on p. 300 of vol. i. (see Fig. 2), which will give the reader some idea as to how snow-blindness may be produced, and which might have reminded Capt. Nares that the expedition was provided with the instrument we speak of. When the sun reaches a certain height, above $14^{\circ}$, during clear weather, "the most brilliant prismatic colours are displayed by each minute snow-prism, and in combination form a sparkling arc on the snow-covered ground, the bright light from which is too powerful for the unprotected eye. The 'diamond-dust,' as we term it, becomes more open as the length of the radius is increased. Consequently, when the sun is between fourteen and twenty-three degrees in altitude, the refraction of its rays is set forth with the greatest effect, and snow-blindness has to be guarded against. In the bright arc, while each tiny prism displays its complete set of colours, the red tint is the most prominent nearest the sun, the purple lying on the outside indistinctly defined.' We regret that such observations were so rare, and that so little use was made by the expedition under Capt. Nares of the fine set of apparatus for physical observations with which it was provided. This is the weak point of the expedition, and, so far as physical science is concerned, the "Arctic Manual" need hardly have been written. The 26 th paragraph of the sailing orders runs :

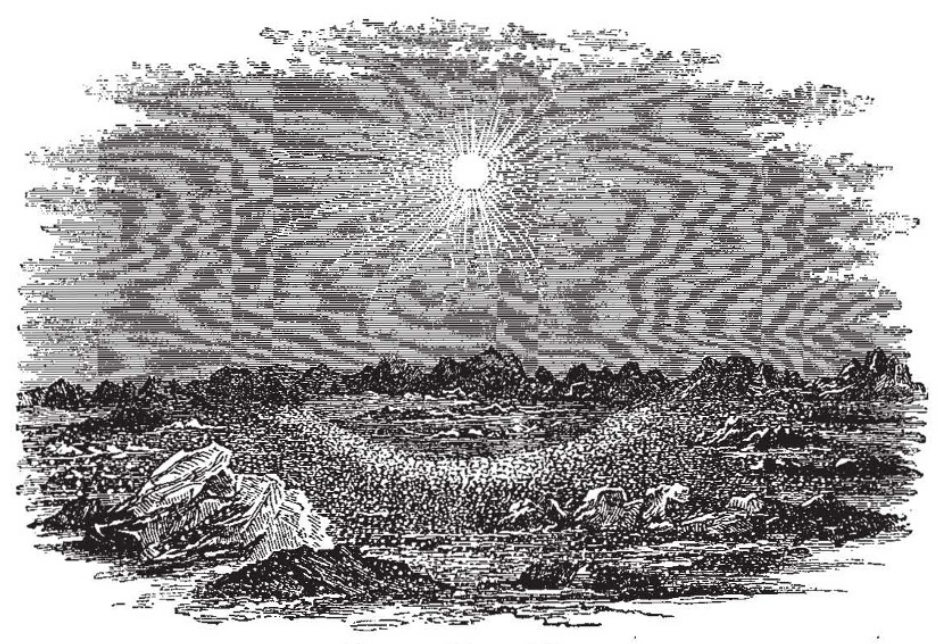

Fig. 2.-Diamond Dust.

"The most approved instruments have been furnished to you for the purpose of pursuing research in the several branches of physical science, and as certain of your officers have been specially instructed in the modes of observing, you will take care to give them every fair opportunity of adding their contributions thereto." Very few "fair opportunities" seem to have occurred to the expedition.

But after all it is doubtful if the commander of the expedition is so much to blame. The truth is that the instructions to the expedition said more than should have been said about trying to reach the pole. What we wanted and what we still want are steady continued observations of meteorological and other phenomena in the polar area. The Royal Society might have saved itself all trouble if the instructions had been published beforehand. The comparative meagreness of the scientific results is, we believe, due more to the tone of the instructions than to Sir George Nares.

Thanks mainly to Capt. Feilden, however, the expedition has not been altogether barren in scientific results, as the Appendix filling half the second volume will testify. With the exception of the short paper on the tides by Dr. Haughton, this appendix deals with the natural history and geology of the region visited. Each of the departments of natural history, from the mammalia downwards, has been worked out by a specialist, and the results, though seldom novel, are all highly interesting. Life was found in the sea at the highest point reached, and not far from the same point the tracks of a hare were seen. Dr. Hooker has some important observations to make in connection with the flora brought home, which confirms his previous conclusions as to the essentially Greenlandish nature of the Greenland flora. $\mathrm{He}$ is inclined to think that regetation may be more abundant in the interior of Greenland than is supposed, and that the glacier-bound coast-ranges of that country may protect a comparatively fertile interior. We are almost driven to conclude, he thinks, that Grinnell Land, as well as Greenland, are, instead of ice-capped, merely ice-girt lands. The geological results are fully and ably discussed by Mr. De Rance and Capt. Feilden, who indeed traverse summarily the whole ground of Arctic geology, to which their paper is a valuable contribution. Their conclusions are essentially the same as those already formed as to the very different climate that must have at one time prevailed in these regions. Dr. Coppinger's report on the great glacier that discharges into the Petermann Fjord is interesting, though his observations do not seem to agree entirely with Dr. Hooker's conclusions.

On the whole Sir George Nares's two volumes confirm the opinions we have already published with regard to this expedition: One and all exerted themselves nobly and bravely to carry out the main object of the expedition; the results, geographical and scientific, brought home are of great value, and repay to a considerable extent the outlay and the hardships endured; at the same time, now that the full narrative has been published, we must express regret that the scientific results are not more abundant than they are, and that they contrast so markedly with those of previous English expeditions, and with the expeditions of Germany and Austria, where, however, the officers are all trained men of science. Notwithstanding the results we cannot regret that the expedition was sent out; it has solved the question of Arctic exploration so far that it is clear the Pole is not to be reached by the Smith Sound route -if at all, indeed by any means hitherto tried -unless some line of land be met with that will enable the sledge to be utilised. Meantime this narrative of the last great English Expedition will prove attractive and instructive to many readers. We cannot conclude without saying a word in praise of the many fine illustrations of Arctic scenery, a number of the finest being permanent Woodburytypes. There is also a large map showing the new discoreries, and a special one of Markham's journeys.

\section{TRANSPLANTATION OF SHELLS}

$\mathrm{T}^{\mathrm{T}}$ is well known that animals and plants inhabiting freshwater have, as a general rule, a very wide distribution; yet each river system, with all the pools and lakes in connection with it, seems completely cut off from every other system of the same country. Still more complete is the separation between the freshwaters of distinct continents or of islands; nevertheless they often possess freshwater species in common. In my "Origin of Species" I have suggested various means of transportal; but as few facts on this head are positively known, the case given in the adjoined letter of a living Unio, which had caught one of the toes of a duck's foot 
between its valves, and was secured in the act of being transported, seems to me well worth recording.

CHARLES DARWIN

DEAR SIR,-The following case will, I think, prove of interest to you, as it corroborates your belief that freshwater shells are some. times transplanted by the agency of aquatic birds.

In the sketch I have endeavoured to give you a correct idea of the way in which the shell was attached to the duck's foot.

It was given to me by Mr. H. L. Newcomb, who shot the bird, which was a bluewinged teal (Querquedula discors), while flying, near the Artichoke river at West Newbury, Mass., September 6, 1877 . The shell, the common mussel, or clam (Unio complanatus), is a very abundant species, being found in nearly all the rivers and ponds of the Atlantic slope. How long the shell had been attached is only a matter of conjecture, but it had abraded the skin of the bird's toe, and left quite an im. pression. It was living when the bird was shot.

It would have undoubtediy been transplanted to some pond or river, perhaps miles from its original home, had the bird not been shot, and might then have propagated its kind.

Da:iversport, Mass, May 8

To C. Darwin, Esq.

\section{THE NATIONAL WATER SUPPLY}

THE?Congress convened by the Society of Arts, at the suggestion of His Royal Highness the Prince of Wales, their President-and which has been presided over by Sir Henry Cole, K.C.B., and numerously attended by Mayors of Provincial Towns, Chairmen of Local Sanitary Authorities, Medical Officers of Health, Members of the Thames Conservancy Board, Engineers, and men of science-may fairly be considered a sufficiently representative body to discuss with some amount of authority a national question.

The papers prepared at the request of the Council of the Society, and discussed by the Congress, may conveniently be divided into three groups:- the quantity of rainfall available for water-supply; the necessity of improved legislation to give it quickly and cheaply to the people; the necessity of compulsory powers being given to a government department, to carry out the amended law.

The first head, quantity available, was appropriately opened by a paper on the rainfall, by Mr. G. J. Symons, the indefatigable head of the 2,000 unpaid observers, whose results leave little to add to our knowledge upon this matter. "No part of the British Isles has, on the average, less than 20 inches of rain per annum," and "the bulk of the supply falls upon elevated mountain tracts, where it ranges from 50.to more than roo inches per annum."

Mr. Symons did not give the results of his experience on the probable amount of the rainfall evaporated on different soils, under different atmospheric conditions, and in different parts of the country; this figure must ever be an important factor in estimating the quantity of water available in a district. Mr. John Evans, F.R.S., however, informed the congress that while on bare hard rocks nearly the whole of the rainfall is carried off by the surface streams, on some porous rocks, such as chalk, an average quantity of not more than six or eight inches per annum finds its way to a depth of three feet from the surface, the remainder being carried off by evaporation, and vegetation, and he adds "that for the supply of the population in districts of different geological character, different means must be adopted."

Numerous speakers insisted at some length on the influence of the varying degree of permeability of the rocks, in determining whether the rainfall is thrown off in floods, which should be collected and stored in reservoirs, or whether it is absorbed into the ground, where it can only be reached by wells, or by carefully preserving lines of springs. Mr. Chadwick, C.B., pointed out that the Map of the Geological Survey of the United Kingdom, and the other publications of this Department, formed an admirable basis for any inquiry into the water-bearing facilities of the British rocks. Mr. Whitaker's Memoir on the London Basin, which contains the particulars of more than 500 wells sunk in and around the Metropolis, is a good illustration of this, and useful as showing the facilities already possessed by a Government. Department, which is capable of greater extension in this direction, and whose officers now constantly work in concert with those of the Local Government Board.

Mr. Lucas exhibited a useful map, showing the underground contours of the surface of the water in the chalk, of some 800 square miles of the Thames and Hampshire basins, so that the level of the water in regard to the Ordnance datum line can be seen at a glance. He has also in some cases indicated the underground level of underlying impermeable strata, a method which has been long used in the Geological Maps of Paris; and it is a matter of surprise that a map of London which should answer the purpose of a section in all directions was not published before. However useful such a map may be amongst the permeable rocks of the greensand, chalk, oolites, and new red sandstones, which are penetrated by deep wells, - -in the more ancient formations, consisting almost entirely of impermeable rocks, it would be impossible to construct such a map, and the ordinary Geological Map is all that is required.

These porous secondary strata occupy an area of 26,000 square miles in England and Wales, and in Scotland and Ireland are practically absent, and wells of any depth are rare; while the more shallow wells, penetrating the overlying drift, are in all districts, as pointed out by the Rivers Pollution Commission, dangerous sources of supply, though in some cases, as Prof. Prestwich, F.R.S., pointed out to the Congress, the gradual removal of cesspools, and improvement of house-drainage, has caused the shallower well-waters to again improve: He, however, gave a remarkable instance of a retrograde character, that of a deep "dry well," being carried through the London clay, to drain a cemetery near London, into the underlying Thanet Sands, which still give an important quota to the Metropolitan potable waters.

Next to the quantity of water available, there is no question so important as the quality and purity; and on this point Dr. Frankland gave important and reassuring evidence; for though he tells us that the increasing pollution of rivers and streams "renders the supply of wholesome water from them more and more difficult," yet "two sources of wholesome water" still remain in England, viz., "upland surface water and subterranean water." The tables accompanying a paper laid before the Congress by Mr. De Rance, show that the formations yielding water of these two characters occupy the following areas in England :-

\section{FORMATIONS YIELDING :-}

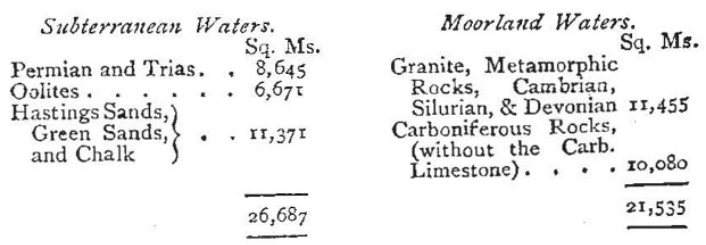

